\title{
PENGARUH PENAMBAHAN TEPUNG GAPLEK DENGAN KONSENTRASI YANG BERBEDA TERHADAP MUTU SILASE CAIR DARI KEPALA UDANG VANAME (Litopenaeus vannamei)
}

\author{
Effect of Acquisition of Cassava Flour With Differentcontributions to The Quality of Liquid Silage From The Heads of \\ Vaname Shrimp (Litopenaeus vannamei) \\ Suriani ${ }^{*}$, Asnani, Kobajashi T. Isamu \\ Jurusan Teknologi Hasil Perikanan, Fakultas Perikanan dan Ilmu Kelautan Universitas Halu Oleo, Kendari, \\ Sulawesi Tenggara, Indonesia
}

*Email korespondensi: suriani.sarda98@gmail.com (Telp: +6282349561874)

Diterima: 9 Januari/ Disetujui 20 Maret 2020

Cara sitasi: Suriani, Asnani, Isamu KT. 2020. Pengaruh penambahan tepung gaplek dengan konsentrasi yang berbeda terhadap mutu silase cair dari kepala udang vaname (Litopenaeus vannamei). Jurnal Fish Protech. 3(1):125-132.

\begin{abstract}
Silage is a liquid product from the process of fermentation of grass, fish or waste that is used as a mixture of feed. Generally silage is made from fish or fish waste. Fish silage is a liquid product made from the remnants of processed fishery products that are not utilized by humans without any other treatment except by acid or by bacterial inoculation. The purpose of this study was to determine the effect of the use of cassava flour on sensory values (color and aroma) and proximate composition (water content, ash content, protein content and $\mathrm{pH}$ ) on the liquid silage of shrimp head. This study used a Completely Randomized Design (CRD) consisting of four treatments with a ratio of cassava flour and shrimp heads respectively: 10: 90\% (P1), 20: 80\% (P2), 30: 70\% (P3) and 40 : 60\% (P4) and repeated three times. Data from observations were analyzed using ANOVA (Analysis of Variance) and DMRT (Duncan Multiple Range Test) tests, each at a 95\% confidence level. The results obtained indicate that the use of cassava flour has a significant influence on the sensory value which includes the color and aroma of liquid shrimp silage. The P1 treatment showed a brownish orange color and a typical silage aroma/odor without additional odor. Proximate composition of silage includes: water content $74.2 \%-82.6 \%$, ash content $1.9 \%-3.2 \%$, protein content $7.4 \%-11.9 \%$ and $\mathrm{pH}$ ranges from $4.3-5.4$.
\end{abstract}

Keywords: Silage, Vaname shrimp head (Litopenaeus vannamei), cassava flour, Sensory Test, Proximate Composition.

ABSTRAK

Silase merupakan produk cair hasil proses fermentasi rerumputan, ikan ataupun limbahnya yang digunakan sebagai campuran pakan. Umumnya silase terbuat dari ikan atau limbah ikan. Silase ikan adalah suatu produk cair yang dibuat dari sisa-sisa olahan hasil perikanan yang tidak dimanfaatkan oleh manusia tanpa perlakuan lain kecuali dengan asam atau dengan inokulasi bakteri. Tujuan penelitian ini adalah untuk mengetahui pengaruh penggunaan tepung gaplek terhadap nilai sensori (warna dan aroma) dan komposisi proksimat (kadar air, kadar abu, kadar protein dan pH) pada silase cair kepala udang. Penelitian ini menggunakan Rancangan Acak Lengkap (RAL) yang terdiri dari empat perlakuan dengan perbandingan tepung gaplek dan kepala udang berturut-turut: 10:90\% (P1), 20:80\% (P2), 30:70\% (P3) dan 40:60\% (P4) dan ulangan sebanyak tiga kali. Data hasil pengamatan dianalisa menggunakan ANOVA (Analysis of Variance) dan uji DMRT (Duncan Multiple Range Test) masing-masing pada taraf kepercayaan 95\%. Hasil penelitian yang diperoleh menunjukkan bahwa penggunaan tepung gaplek memberikan pengaruh yang nyata terhadap nilai sensori yang meliputi warna dan aroma silase cair kepala udang. Perlakuan P1 menunjukkkan warna jingga kecoklatan dan aroma/bau asam khas silase tanpa bau tambahan. Komposisi proksimat silase meliputi: kadar air $74,2 \%-82,6 \%$, kadar abu 1,9\%-3,2\%, kadar protein 7,4\%-11,9\% dan pH berkisar 4,3-5,4.

Kata kunci: Silase, Kepala udang vaname (Litopenaeus vannamei), Tepung gaplek, Uji Sensori dan Komposisi Proksimat 


\section{PENDAHULUAN}

Udang merupakan salah satu komoditi penting perikanan yang pada saat ini mengalami peningkatan produksi terutama dari hasil budidaya dan pada umumnya diekspor dalam bentuk beku. Proses pembekuan udang untuk ekspor $60-70 \%$ dari berat udang menjadi limbah. Limbah tersebut berupa cangkang yang mudah sekali busuk sehingga dapat menimbulkan pencemaran lingkungan (Azhar et al., 2010). Di Indonesia saat ini ada sekitar 170 industri pengolahan udang dengan kapasitas produksi sekitar 500.000 ton per tahun. Diperkirakan dari proses pengolahan oleh seluruh unit pengolahan yang ada, akan dihasilkan limbah sebesar 325.000 ton per tahun (Departemen Kelautan dan Perikanan Republik Indonesia, 2006).

Kementerian Kelautan dan Perikanan (2011) memprediksi produksi udang Indonesia pada periode 2010-2014 meningkat $74,75 \%$ atau menjadi 699 ribu ton, terdiri atas 500 ribu ton udang jenis vaname dan 199 ribu ton udang windu. Apabila udang segar ini diolah menjadi udang beku, sebanyak $75 \%$ dari berat total udang menjadi limbah, yaitu bagian cangkang dan kepala (Kelly et al., 2005). Erwan dan Resmi (2004) melaporkan bahwa limbah udang mempunyai kandungan nutrisi yang cukup tinggi dan hampir menyamai kandungan nutrisi tepung ikan yaitu dengan kandungan protein kasar $46,20 \%$, lemak kasar $4,20 \%$, serat kasar $16,85 \%$, kalsium $5,72 \%$, phospor $1,77 \%$ dan ME $2397 \mathrm{Kkal} / \mathrm{kg}$. Limbah udang sangat potensial dijadikan bahan pakan sumber protein hewani karena ketersediaannya cukup banyak dan mengandung nutrisi yang tinggi, terutama protein (Okaye et al., 2005 dan Khempaka et al., 2006). Salah satu bentuk pengolahan pakan ternak dari limbah kepala udang adalah produk silase.

Silase merupakan produk cair hasil proses fermentasi rerumputan, ikan ataupun limbahnya yang digunakan sebagai campuran pakan ternak. Umumnya silase terbuat dari ikan atau limbah ikan.Silase ikan adalah suatu produk cair yang dibuat dari sisa-sisa olahan hasil perikanan yang tidak dimanfaatkan oleh manusia tanpa perlakuan lain kecuali dengan asam atau dengan inokulasi bakteri. Menurut penelitian Ariesta (2007), kadar protein dari silase kepala udang windu dengan penambahan tepung tapioka sebanyak 30-50\% dihasilkan berkisar antara 16,68\%-18,08\%. Cairan silase terbentuk sebagai akibat dari aktifitas enzim proteolitik seperti cathepsin yang terdapat pada ikan tersebut (Kompiang dan llyas 1983). Fermentasi terbagi menjadi dua cara, yaitu fermentasi secara spontan dan tidak spontan (penambahan inokulum/starter).

Salah satu bakteri yang berperan penting pada fermentasi adalah bakteri asam laktat. Menurut Sumarsih et al., (2010), karbohidrat merupakan nutrisi bagi bakteri asam laktat agar bisa memperbanyak diri dan menghasilkan asam laktat yang cukup untuk menekan pertumbuhan mikrobia merugikan. Kandungan karbohidrat pada kepala udang vaname yaitu sekitar $0,10 \%$. Kurangnya kandungan karbohidrat yang terdapat pada kepala udang sehingga harus ditambahkan tepung gaplek. Tepung gaplek adalah salah satu bahan yang dapat ditambahkan sebagai sumber karbohidrat dalam proses pembuatan silase cair.

Tepung gaplek adalah bahan makanan yang diolah dari ubi ketela pohon atau singkong yang dikupas dan dikeringkan dan kemudian dijadikan tepung. Tepung gaplek memiliki kandungan nutrisi yang dapat memproduksi asam laktat sehingga dapat meningkatkan kualitas nutrisi silase (Desnita et al., 2015). Penambahan tepung gaplek dapat mempercepat penurunan $\mathrm{pH}$ karena tepung gaplek menyediakan karbohidrat yang tinggi yang digunakan oleh bakteri asam laktat.

Penelitian ini dilakukan dengan tujuan untuk mengetahui pengaruh penambahan tepung gaplek dengan konsentrasi yang berbeda terhadap nilai sensori (warna dan aroma) dan komposisi proksimat (kadar air, kadar abu, kadar protein dan pH) terhadap silase cair kepala udang. 


\section{Alat dan Bahan}

\section{METODE PENELITIAN}

Alat yang digunakan dalam pembuatan silase serta analisis kimia adalah blender (Miyako), pengaduk, baskom, kain saring, toples kaca, gelas ukur (pyrex), timbangan analitik (Matrix), oven (Memmert un 55), tanur (Furnace D550), cawan porselin (Pyrex), labu kjedahl, soxhlet (Pyrex), desikator (Duran), kertas saring, erlenmeyer (Pyrex), kompor listrik, $\mathrm{pH}$ meter dan alat destilasi.

Bahan yang digunakan dalam penelitian ini adalah kepala udang yang digunakan diperoleh dari PT. Yanagi Histalaraya, tepung gaplek (Gaplek mamie), garam, gula dan kubis untuk pembuatan starter bakteri asam laktat. Bahan-bahan yang digunakan untuk analisa kimia adalah $\mathrm{H}_{2} \mathrm{SO}_{4}, \mathrm{H}_{3} \mathrm{BO}_{3}, \mathrm{HCl}$, pelarut heksan dan larutan standar protein.

\section{Rancangan Penelitian}

Penelitian ini menggunakan Rancangan Acak Lengkap (RAL) yang terdiri dari 4 perlakuan yaitupenambahan tepung gaplek berturut-turut: 10, 20, 30 , dan 40\%. Masing-masing perlakuan diulang 3 kali sehingga diperoleh jumlah satuan percobaan 12 unit.

\section{Pembuatan Silase Ikan \\ Penyiapan Kepala Udang}

Kepala udang dicuci dengan air mengalir sebanyak 2 kali kemudian ditiriskan selama 10 menit sampai air tidak menetes lagi. Kemudian dilakukan proses penghalusan menggunakan blender sehingga diperoleh bubur kepala udang lalu diolah sesuai dengan perlakuan.

\section{Pembuatan Starter}

Sebanyak $1 \mathrm{~kg}$ kubis dicuci dan ditiriskan, kemudian didiamkan selama 12 jam pada suhu ruang untuk proses pelayuan. Kubis yang telah layu kemudian dirajang sehingga diperoleh potongan kecil dengan kisaran 1-2 cm. Potongan kecil tersebut dimasukkan kedalam toples kemudian ditambah garam sebanyak $2,5 \%$, gula $1 \%$ dan air sebanyak 1 liter (sampai kubis terendam). Selanjutnya dilakukan fermentasi selama 4 hari dimana saat itu telah tercium bau asam (starter bakteri siap digunakan).

\section{Pembuatan Silase}

Tabel 1. Formulasi pembuatan silase cair kepala udang vaname dengan penambahan tepung gaplek dengan konsentrasi yang berbeda

\begin{tabular}{lcccc}
\hline \multirow{2}{*}{ Bahan } & \multicolumn{4}{c}{ Formulasi } \\
\cline { 2 - 5 } & $\mathrm{P} 1$ & $\mathrm{P} 2$ & $\mathrm{P} 3$ & $\mathrm{P} 4$ \\
\hline Kepala udang & $90 \%$ & $80 \%$ & $70 \%$ & $60 \%$ \\
$\begin{array}{l}\text { Tepung gaplek } \\
\begin{array}{l}\text { Starter (asinan } \\
\text { kubis)/(ml/300g }\end{array}\end{array}$ & $10 \%$ & $20 \%$ & $30 \%$ & $40 \%$ \\
bahan) & 54 & 54 & 54 \\
\hline
\end{tabular}

Bubur kepala udang dan tepung gaplek masingmasing ditimbang dengan formulasi seperti pada Tabel 1, lalu dimasukkan kedalam toples dan ditambahkan starter cair dari asinan kubis sebanyak $54 \mathrm{ml} / 300$ bahan. Kemudian campuran bubur kepala udang diaduk hingga merata. Kemudian dilakukan pengukuran $\mathrm{pH}$ menggunakan kertas lakmus universal test paper sebelum fermentasi, dan menunjukkan $\mathrm{pH}$ 6. Fermentasi campuran bubur kepala udang dilakukan selama 14 hari. Selanjutnya dilakukan penyaringan menggunakan kain batis untuk memisahkan ampas silase dan cairan silase (disebut silase cair).

\section{Parameter Uji}

Pengujian mutu silase cair yang dilakukan meliputi: uji sensori (warna dan aroma), uji pH, uji kadar air (AOAC 2005), uji kadar abu (AOAC 2005) dan kadar protein (AOAC 2005)

\section{Analisis Data}

Data hasil penelitian sensori dianalisis menggunakan sidik ragam (Anova), jika terdapat perbedaan yang sangat nyata kemudian akan diuji lanjut menggunakan uji jarak berganda DMRT (Duncan Multiple Range Test) dengan taraf kepercayaan $95 \%(a=0,05)$. 


\section{HASIL DAN PEMBAHASAN}

\section{Komposisi Proksimat}

a. Kadar Air

Tabel 2. Rerata nilai kadar air silase

\begin{tabular}{lll}
\hline Perlakuan & $\begin{array}{l}\text { Rata-rata nilai kadar air } \\
\pm S D\end{array}$ & DMRT0,05 \\
\hline P1 & $82,6 \pm 0,25^{\mathrm{b}}$ & \\
P2 & $81,1 \pm 0,24^{\mathrm{b}}$ & \\
P3 & $77,3 \pm 0,84^{\mathrm{a}}$ & $2=0,97$ \\
P4 & $74,2 \pm 0,60^{\mathrm{a}}$ & $3=1,04$ \\
\hline
\end{tabular}

Keterangan : Penggunaan tepung gaplek dan kepala udang berturut-turut: 10:90 (P1), 20:80 (P2), 30:70 (P3), 40:60 (P4). Angka - angka yang diikuti huruf yang berbeda pada kolom yang sama, menunjukkan beda nyata pada taraf kepercayaan $95 \%$

Hasil nilai rata-rata kadar air pada silase dengan penambahan tepung gaplek menunjukkan nilai tertinggi terdapat pada perlakuan $\mathrm{P} 1$ yaitu 82,6 dan terendah terdapat pada perlakuan P4 yaitu 74,2 . Hasil pengujian menunjukkan bahwa rerata nilai kadar air silase dengan penambahan tepung gaplek terhadap perlakuan yang diberikan dapat menurunkan kadar air pada silase. Penurunan kadar air diduga karena penambahan tepung gaplek, hal ini disebabkan karena tepung gaplek dapat mengikat air pada bahan. Tingginya kandungan BETN 93,29\% pada tepung gaplek dapat menurunkan kadar air hal ini sesuai dengan pendapat Galyean (1980), bahan ekstrak tanpa nitrogen merupakan karbohidrat mudah larut dalam air yang mengandung gula dan pati. Hasil nilai uji kadar air pada penelitian ini sesuai dengan penelitian Wardhani (2007), hasil kadar air menurun seiring dengan penambahan jumlah konsentrasi molase yaitu pada penambahan molase $5 \%$ diperoleh $88,99 \%$ dan setelah penambahan molase sebanyak $25 \%$ kadar air yang diperoleh $75,21 \%$.

\section{b. Kadar Abu}

Tabel 3. Rerata nilai kadar abu silase limbah kepala udang

\begin{tabular}{|c|c|c|}
\hline Perlakuan & $\begin{array}{l}\text { Rata-rata nilai kadar abu } \\
\pm S D\end{array}$ & $\mathrm{DMRT}_{0,05}$ \\
\hline $\mathrm{P1}$ & $1,9 \pm 0,11^{a}$ & \\
\hline $\mathrm{P} 2$ & $2,1 \pm 0,13^{b}$ & \\
\hline P3 & $2,8 \pm 0,11^{c}$ & $2=0,140$ \\
\hline P4 & $3,2 \pm 0,03^{d}$ & $3=0,149$ \\
\hline terangan & $\begin{array}{l}\text { Penggunaan tepung gaplek da } \\
\text { berturut-turut: 10:90 (P1), 20:80 } \\
\text { 40:60 (P4). Angka - angka yang c } \\
\text { berbeda pada kolom yang sam } \\
\text { beda nyata pada taraf kepercayaa }\end{array}$ & $\begin{array}{l}\text { kepala udang } \\
\text { 2), } 30: 70(\mathrm{P} 3) \text {, } \\
\text { kuti huruf yang } \\
\text { menunjukkan } \\
95 \% \text {. }\end{array}$ \\
\hline
\end{tabular}

Abu adalah zat anorganik sisa hasil pembakaran suatu bahan. Kadar abu bahan erat kaitannya dengan kandungan mineral bahan tersebut. Berbagai mineral dalam bahan ada di dalam abu saat dibakar (Legowo dan Nurwantoro, 2004). Hasil nilai rerata kadar abu pada silase dengan penambahan tepung gaplek menunjukkan nilai tertinggi terdapat pada perlakuan P4 yaitu 3,2 dan terendah terdapat pada perlakuan P1 yaitu 1,9. Semakin banyak penambahan konsentrasi tepung gaplek maka akan terjadi peningkatan pada kadar abu. Peningkatan kadar abu diduga disebabkan oleh mineral yang terdapat pada bahan. Kandungan kadar abu dapat meningkat karena tepung gaplek yang digunakan memiliki kadar abu sekitar 1,69\%. Menurut Sudarmadji dan Bambang (2003), kadar abu pada pakan berhubungan dengan kadar mineral yang terdapat pada pakan tersebut. Semakin tingggi kadar abu, semakin tinggi mineralnya. Hasil nilai uji kadar abu pada penelitian ini sama dengan kadar abu penelitian Supriyanto (2015) dimana semakin banyak penambahan Konsentrasi tepung kiambang pada tepung silase limbah ikan gabus maka kadar abu akan meningkat yaitu pada penambahan $0 \%$ kadar abu diperoleh 7,49 dan setelah penambahan tepung kiambang sebanyak $20 \%$ kadar abu mengalami peningkatan menjadi $23,10 \%$. 


\section{c. Kadar Protein}

Tabel 4. Rerata nilai kadar protein silase

\begin{tabular}{lll}
\hline Perlakuan & $\begin{array}{l}\text { Rata-rata nilai kadar protein } \\
\pm S D\end{array}$ & DMRT $_{0,05}$ \\
& $11,9 \pm 0,48^{\mathrm{d}}$ & \\
P1 & $10,3 \pm 0,24^{\mathrm{c}}$ & \\
P2 & $8,6 \pm 0,24^{\mathrm{b}}$ & $2=0,64$ \\
P3 & $3,4 \pm 0,47^{\mathrm{a}}$ & $3=0,66$ \\
P4 & \\
\hline
\end{tabular}

Keterangan : Penggunaan tepung gaplek dan kepala udang berturut-turut: 10:90 (P1), 20:80 (P2), 30:70 (P3), 40:60 (P4). Angka - angka yang diikuti huruf yang berbeda pada kolom yang sama, menunjukkan beda nyata pada taraf kepercayaan $95 \%$.

Protein merupakan makromolekul yang tersusun oleh asam-asam amino yang mengandung unsur-unsur $\mathrm{C}, \mathrm{H}, \mathrm{O}$ dan $\mathrm{N}$ (Legowo dan Nurwantoro 2004). Berdasarkan penambahan tepung gaplek dengan konsentrasi yang berbeda, kadar protein mengalami penurunan, pada perlakuan P1 menghasilkan kadar protein sebanyak 11,9 dan pada perlakuan P4 menghasilkan kadar protein sebanyak 7,4. Kadar Protein silase setelah difermentasi mengalami penurunan disebabkan karena penambahan tepung gaplek dengan jumlah yang berbeda. Hal ini sesuai dengan penelitian Setiawati (2002), yang menyatakan bahwa salah satu faktor yang menyebabkan turunnya kandungan protein silase ikan adalah penambahan additive. Semakin tinggi penambahan additive dalam pembuatan silase ikan akan semakin menurunkan kandungan protein. Hal ini sesuai dengan penelitian Wardhani (2007), Semakin banyak molase yang ditambahkan pada silase maka semakin banyak pula bakteri yang tumbuh.

Hasil nilai uji kadar protein pada penelitian ini sesuai dengan nilai uji pH sifat fisik, kimia serta kandungan nutrisi silase ikan yang diberi additive tape dan gaplek dari hasil penelitian Setiawati (2002), hasil kadar protein menurun seiring dengan penambahan jumlah konsentrasi tepung gaplek yaitu dengan penambahan tepung gaplek sebanyak $10 \%$ diperoleh nilai kadar protein $44,59 \%$ dan setelah penambahan tepung gaplek $30 \%$ kadar protein menurun menjadi $30,17 \%$. d. $\mathrm{pH}$

Tabel 5. Rerata nilai pH silase

\begin{tabular}{|c|c|c|}
\hline Perlakuan & $\begin{array}{l}\text { Rata-rata nilai } \\
\mathrm{pH} \\
\pm \mathrm{SD}\end{array}$ & DMRT $_{0,05}$ \\
\hline P1 & $5,4 \pm 0,05^{b}$ & \\
\hline P2 & $5,2 \pm 0,03^{b}$ & \\
\hline P3 & $4,4 \pm 0,01^{a}$ & $2=0,039$ \\
\hline P4 & $4,3 \pm 0,01^{a}$ & $3=0,042$ \\
\hline
\end{tabular}

Keterangan : Penggunaan tepung gaplek dan kepala udang berturut-turut: 10:90 (P1), 20:80 (P2), 30:70 (P3), 40:60 (P4). Angka - angka yang diikuti huruf yang berbeda pada kolom yang sama, menunjukkan beda nyata pada taraf kepercayaan $95 \%$.

Derajat keasaman $(\mathrm{pH})$ merupakan salah satu faktor lingkungan yang berpengaruh terhadap pertumbuhan dan aktivitas bakteri pengoksidasi amonia (Esoy et al., 1998). Hasil nilai rerata pH pada silase dengan penambahan tepung gaplek menunjukkan nilai $\mathrm{pH}$ tertinggi terdapat pada perlakuan $\mathrm{P} 1$ yaitu 5,4 dan terendah terdapat pada perlakuan $\mathrm{P} 4$ yaitu 4,3 . Penurunan nilai $\mathrm{pH}$ pada silase diduga karena penambahan tepung gaplek berpengaruh terhadap kecepatan pertumbuhan bakteri asam laktat sebagai sumber karbohidrat, dimana semakin tinggi penambahan konsentrasi tepung gaplek yang digunakan maka, $\mathrm{pH}$ silase semakin rendah. Hal ini didukung dengan pendapat Perry et al. (2003) dalam Jasin (2015), menyatakan bahwa penambahan bahan kaya akan karbohidrat dapat mempercepat penurunan $\mathrm{pH}$ silase karena karbohidrat merupakan energi bagi bakteri pembentuk asam laktat. Hasil nilai uji pH pada penelitian ini lebih rendah dari nilai uji pH sifat fisik, kimia serta kandungan nutrisi silase ikan yang diberi additive tape dan gaplek dari hasil penelitian Setiawati (2002), nilai $\mathrm{pH}$ dengan penambahan tepung gaplek 10\% diperoleh $\mathrm{pH}$ sekitar 7,47 dan setelah penambahan $30 \%$ tepung gaplek diperoleh nilai $\mathrm{pH}$ yaitu $6,48 \%$. 


\section{Uji Sensori}

a. Warna

Tabel 7. Rerata nilai warna silase dari kepala udang

\begin{tabular}{llll}
\hline Perlakuan & $\begin{array}{l}\text { Rata-rata nilai warna } \\
\pm S D\end{array}$ & Kategori & DMRT 0,05 \\
\hline P1 & $4,7 \pm 0,31^{\text {a }}$ & Coklat & \\
P2 & $5,4 \pm 0,31^{\mathrm{b}}$ & Coklat & \\
P3 & $7,9 \pm 0,30^{\mathrm{c}}$ & Jingga kecoklatan & $2=0,44$ \\
P4 & $8,3 \pm 0,26^{\mathrm{c}}$ & Jingga kecoklatan & $3=0,48$
\end{tabular}

Keterangan : Penggunaan tepung gaplek dan kepala udang berturut-turut: 10:90 (P1), 20:80 (P2), 30:70 (P3), 40:60 (P4). Angka angka yang diikuti huruf yang berbeda pada kolom yang sama, menunjukkan beda nyata pada taraf kepercayaan $95 \%$.

Warna merupakan salah satu nilai fisik untuk menentukan kriteria silase ikan. Menurut Sulistyono (1976) dalam Handajani (2014), warna silase ikan yang baik ialah warna yang sesuai dengan warna bahan atau bubur ikan sebelum ditambah bahan pembuat silase, artinya tidak ada perubahan warna silase ikan selama proses pengeraman atau fermentasi.

Hasil uji sensori terhadap warna pada produk silase kepala udang dengan penambahan tepung gaplek menunjukkan nilai rerata tertinggi pada perlakuan P4 dengan nilai 8,3 dengan kriteria Jingga kecoklatan dan nilai terendah pada perlakuan P1 dengan nilai 4,7 dengan kriteria coklat. Warna silase yang dihasilkan berbeda-beda karena penambahan konsentrasi tepung gaplek yang berbeda. Warna silase yang dihasilkan pada penelitian ini diduga sangat dipengaruhi oleh penambahan tepung gaplek yang berwarna putih kecoklatan. Perubahan warna yang terjadi dari semua perlakuan dan tidak adanya warna yang menyerupai warna bubur udang dikarenakan selama proses fermentasi terjadi proses biokimiawi yang dapat merubah warna silase. Hasil warna penelitian ini berbeda dengan warna silase ikan dari penelitian Handajani (2014), yaitu berwarna abuabu.

\section{b. Aroma}

Tabel 8. Rerata nilai aroma silase dari kepala udang

\begin{tabular}{llll}
\hline Perlakuan & $\begin{array}{l}\text { Rata-rata nilai Aroma } \\
\pm S D\end{array}$ & Kategori & DMRT 0,05 \\
\hline P1 & $5,0 \pm 0,32^{\mathrm{a}}$ & Sedikit bau asam, tidak khas silase, ada bau tambahan & \\
P2 & $5,5 \pm 0,36^{\mathrm{a}}$ & Sedikit bau asam, tidak khas silase, ada bau tambahan & \\
P3 & $7,4 \pm 0,50^{\mathrm{b}}$ & Ada bau asam, khas silase, ada bau tambahan & $2=0,41$ \\
P4 & $8,6 \pm 0,06^{\mathrm{c}}$ & Ada bau asam, khas silase, tanpa bau tambahan & $3=0,44$ \\
\hline
\end{tabular}

Keterangan : Penggunaan tepung gaplek dan kepala udang berturut-turut: 10:90 (P1), 20:80 (P2), 30:70 (P3), 40:60 (P4). Angka angka yang diikuti huruf yang berbeda pada kolom yang sama, menunjukkan beda nyata pada taraf kepercayaan $95 \%$.

Nilai aroma merupakan bagian dari penilaian fisika yang dilakukan untuk menguji kualitas silase ikan yang dibuat dengan berbagai jenis asam organik dan bakteri asam laktat (Handajani, 2014). Hasil uji sensori terhadap aroma dari silase kepala udang menunjukkan nilai rerata tertinggi terdapat pada perlakuan P4 dengan nilai 8,6 sedangkan nilai rerata terendah terdapat pada perlakuan P1 dengan nilai sebesar 5,0. Penambahan tepung gaplek dengan konsentrasi yang berbeda diduga dapat menurunkan $\mathrm{pH}$ silase sehingga aroma silase berbau asam. Semakin banyak tepung gaplek yang ditambahkan maka dapat merangsang pertumbuhan bakteri asam laktat dan sebaliknya semakin sedikit penambahan 
tepung gaplek maka sulit merangsang pertumbuhan bakteri pembentuk asam dilihat dari $\mathrm{pH}$ pada $\mathrm{P} 1$ yang sangat tinggi. Tingginya $\mathrm{pH}$ pada silase dapat mempengaruhi aroma silase menjadi busuk karena adanya asam butirat. Asam butirat dan $\mathrm{NH}_{3}$ merupakan zat yang berbau tidak enak.

Menurut McDonald et al. (2002) yang menyatakan bahwa pemecahan asam amino dan pembentukan ammonia sebagian besar dilakukan oleh bakteri Clostridium. Pada fermentasi ini asam laktat dipecah menjadi asam butirat, selain itu juga terjadi diaminasi dan dekarboksilasi asam amino membentuk ammonia $\left(\mathrm{NH}_{3}\right)$. Hasil aroma pada penelitian ini sesuai dengan aroma silase ikan dari penelitian Handajani (2014), yaitu beraroma asam.

\section{DAFTAR PUSTAKA}

Azhar, M., Efendi, J., Syofyeni, E., Lesi, M.R dan Novalina, S. 2010. Pengaruh Konsentrasi $\mathrm{NaOH}$ dan $\mathrm{KOH}$ terhadap Derajat Deasetilasi Kitin dari Kulit Udang. Eksakta 1(11):1-8.

AOAC. 2005. Official Methods of Analysis. 18th ed. Association of Official Analytical Chemists, Washington DC.

Ariesta, A. 2007. Karakteristik Mutu dan Kelarutan Kitosan dari Ampas Silase Kepala Udang Windu (Penaeus monodon) [Skripsi]. Bogor: Fakultas Perikanan dan IImu Kelautan. Institut Pertanian Bogor.

Departemen Kelautan dan Perikanan Republik Indonesia, 2006, Industri Kitin: Dari Limbah Menjadi Bernilai Tambah, Jakarta.

Desnita, D., Widodo, Y dan YS, S. T. 2015. Pengaruh Penambahan Tepung Gaplek dengan Level yang Berbeda Terhadap Kadar Bahan Kering dan Kadar Bahan Organik Silase Limbah Sayuran. Jurnal Ilmiah Peternakan Terpadu Vol. 3 (3): 140-144.

Erwan, E dan Resmi. 2004. Performans Ayam Lurik yang diberi Tepung Limbah Udang Olahan

\section{KESIMPULAN}

Berdasarkan hasil penelitian dan pembahasan, maka dapat disimpulkan sebagai berikut:

1. Perlakuan penambahan tepung gaplek dengan konsentrasi yang berbeda pada silase terhadap parameter uji sensori yang diamati berpengaruh nyata terhadap warna dan aroma. Silase kepala udang vaname diperoleh hasil terbaik uji sensori warna dengan penambahan $40 \%$ tepung gaplek yaitu 8,3 dan uji sensori aroma dengan penambahan $40 \%$ tepung gaplek yaitu yaitu 8,6 .

2. Hasil uji kimia silase dengan penambahan tepung gaplek dengan konsentrasi yang berbeda yang diamati berpengaruh nyata terhadap kadar air, kadar abu, kadar protein dan $\mathrm{pH}$. Nilai kadar air berkisar antara $74,2 \%-82,6 \%$, kadar abu 1,9\%$3,2 \%$, kadar protein $7,4 \%-11,9 \%$ dan $\mathrm{pH} 4,3-5,4$.

sebagai pengganti Tepung Ikan dalam

Ransom. Jurnal IImu-IImu Peternakan. Vol. II

No. 1 Edisi Februari 2004. Fakultas

Peternakan Universitas Jambi.

Esoy, A., H. Odegaard and G. Bentzen. 1998. The Effect of Sulphide and Organic Matter on The Nitrification Activity In Biofilm Procces. Water Science Technology 37 (1): 115- 122.

Galyean ML. 1980. Laboratory Procedures in Animal Nutrition Research. Lubbock (US): Texas Tech University.

Handajani, H. 2014. Peningkatan Kualitas Silase

Limbah Ikan Secara Biologis dengan

Memanfaatkan Bakteri Asam Laktat. Jurnal

Gamma, ISSN 0216-9037 Volume 9, Nomor 2: $31-39$.

Jasin, I. 2015.Pengaruh Penambahan Tepung

Gaplek dan Isolat Bakteri Asam Laktat dari

Cairan Rumen Sapi PO Terhadap Kualitas

Silase Rumput Gajah (Pennisetum

purpureum). Jurnal Peternakan Vol (15) No. 1 :

52-56.

Kelly C. G, Agbagbo F. K, Holtzapple M. T. 2005.

Lime treatment of shrimp headwaste for the 
generation of highly digestible animal feed. J of Bioresource Technology 97:1515-1320.

Kementerian Perikanan dan Kelautan. 2011. Potensi Limbah Udang di Indonesia menjadi Khitosan. Laporan Tahunan DPK, Jakarta.

Khempaka, S., K. Koh and Y. Karasawa. 2006. Effect of shrimp meal on growth performance and digestibility in growing broiler. J. Puoltry Sci., 43: $250-254$.

Kompiang, I. P., S. llyas. 1983. Pembuatan Silase Ikan dengan Penggunaan Asam Formiat. Jurnal Peneltian Teknologi Hasil Perikanan.2:30-35.

Legowo AM, Nurwantoro. 2004. Analisis Pangan. Semarang (ID): Universitas Diponegoro Press. McDonald, P., R.A. Edwards, J.F.D. Greenhalgh, and C.A. Morgan. 2002. Animal Nutrition, 6th Ed. Prentice Hall, London.

Okaye, F.C., G.S. Ojewola, and K. Njoku- Onu. 2005. Evaluation of shrimp waste meal as a probable animal protein source for broiler chicken. International Journal of Poultry Science 12: $456-461$.

Sudarmadji SH, Bambang. 2003. Prosedur Analisa Bahan Makanan Dan Pertanian. Yogyakarta: Liberty.

Sumarsih, S., Sulistiyanto, B., Adi, S.H dan Utama, S.C. 2010. Pengaruh Aras Starter Lactobacillus sp. terhadap Performa Mikrobiologi Silase Ikan dilihat dari Total Bakteri, Bakteri Asam Laktat dan Fungi. Jurnal KesehatanVol.3, No.I, Juni 2010 (43-50).

Supriyanto, A., Baehaki, A, dan Hanggita, S. 2015. Karakteristik Fisik dan Kimia Tepung Silase Limbah Ikan Gabus (Channa striata) dengan Penambahan Konsentrasi Tepung Kiambang Terfermentasi. Jurnal Teknologi Hasil

Perikanan, Vol. 4 No. 2.

Setiawati, A. 2002. Sifat fisik, Kimia serta Kandungan Nutrisi Silase Ikan yang diberi Additive Tape dan Gaplek [Skripsi]. Bogor: Fakultas Peternakan. Institut Pertanian Bogor. Wardhani, I.K. 2007. Mempelajari Mutu Silase dan Kitosan dari Ampas Silase Limbah Udang.
Skripsi, Fakultas Perikanan dan Ilmu Kelautan, Institut Pertanian Bogor. Bogor. 60 hal 